\title{
Mechanical ventilation and cardiopulmonary bypass: a narrative review of the mechanistic lung protective measures
}

\author{
Marco Echeverria-Villalobos, Dolly M. Munlemvo, Juan Fiorda-Diaz, Michael K. Essandoh \\ Department of Anesthesiology, The Ohio State University Wexner Medical Center, Columbus, OH 43210, USA.
}

Correspondence to: Prof. Juan Fiorda-Diaz, Department of Anesthesiology, The Ohio State University Wexner Medical Center, Columbus, OH 43210, USA. E-mail: Juan.Fiorda@osumc.edu

How to cite this article: Echeverria-Villalobos M, Munlemvo DM, Fiorda-Diaz J, Essandoh MK. Mechanical ventilation and cardiopulmonary bypass: a narrative review of the mechanistic lung protective measures. Vessel Plus 2019;3:33.

http://dx.doi.org/10.20517/2574-1209.2019.12

Received: 19 Apr 2019 First Decision: 9 Aug 2019 Revised: 9 Aug 2019 Accepted: 13 Aug 2019 Published: 17 Sep 2019

Science Editor: Mario F. L. Gaudino Copy Editor: Jia-Jia Meng Production Editor: Tian Zhang

\begin{abstract}
Postoperative pulmonary dysfunction is a multifactorial complication in patients undergoing cardiac surgery with cardiopulmonary bypass (CPB). Numerous risk factors including individual, surgery- and anesthesia-related have been identified. Exacerbated systemic and pulmonary inflammatory response to CPB is one of the most studied mechanisms of lung injury in this patient setting. However, current literature lacks specific intraoperative mechanical ventilation (MV) strategies associated with a significant improvement in patients' outcomes. We reviewed the randomized clinical trials and other reports published within the last 5 years involving patients undergoing cardiac surgery with CPB in order to summarize the existing MV strategies used in these patients and their associated outcomes. Moreover, we described the pathophysiological mechanisms involved in post- CPB lung injury and the mechanistic effects of protective ventilation.
\end{abstract}

Keywords: Cardiopulmonary bypass, mechanical ventilation, postoperative pulmonary complications, protective mechanical ventilation

\section{INTRODUCTION}

Impaired postoperative pulmonary function is a common and multifactorial complication after cardiac surger $^{[1,2]}$. Exacerbated cellular and humoral activation is a widely-known response ensuing from cardiopulmonary bypass $(\mathrm{CPB})$, being the major cause of postoperative lung injury ${ }^{[3,4]}$. Protective

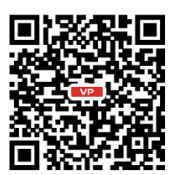


mechanical ventilation (PMV) strategies such as the use of continuous positive airway pressure (CPAP) have shown benefits in non-cardiac surgeries ${ }^{[2]}$. Likewise, CPAP, low tidal volume $\left(\mathrm{V}_{\mathrm{T}}\right)$ and recruitment maneuvers have been used in patients undergoing cardiac surgeries under $\mathrm{CPB}$ aiming to ameliorate lung mechanics and to decrease postoperative pulmonary complications (PPCs) $)^{[5,6]}$.

Mild respiratory dysfunction is commonly reported after cardiac surgery under CPB with a small percentage of patients developing severe lung dysfunction ${ }^{[7]}$. Even though protective ventilation strategies have been associated with decreased levels of pro-inflammatory cytokines and improved lung mechanics, its impact on other postoperative long-term outcomes such as PPCs and hospital length of stay (LOS) remains unclear.

A comprehensive review of current literature was carried out aiming to describe the pulmonary physiopathological changes experienced by patients undergoing cardiac surgery with and without $\mathrm{CPB}$ and treated under different ventilation strategies. Likewise, the incidence of PPCs in patients with and without continuous MV during $\mathrm{CPB}$ was analyzed.

\section{METHODS}

A literature search on PubMed, Embase, and Cochrane Library databases was carried out in order to identify manuscripts published between 01 Jan 2014 and 31 Jan 2019 describing MV and pulmonary complications in patients undergoing CPB surgery. We used Medical Subject Headings involving the terms "MV" (combined with "СРB", "СРB and lung injury", "CPB and morbidity", "CPB and mortality", "CPB and pulmonary perfusion", "cardiac surgery and oxygen diffusion"), "CPB" [combined with "pulmonary complications", "CPAP", "positive end-expiratory pressure (PEEP)", "lung injury", "lung mechanics"], and "lung protective ventilation in CPB surgery". Our search was limited to manuscripts in English language, involving adult patients only, clinical trials (including phase I-IV studies), narrative reviews, and systematic reviews (with or without meta-analysis). Case reports were only considered if they were needed to support specific clinical findings not previously discussed. Moreover, we excluded manuscripts referring to CPB surgery outside the scope of this review, conference abstracts, thesis, and trials involving children or patients undergoing other cardiac surgeries different from CPB.

\section{RESULTS}

Initially, we identified 207 manuscripts out of which 46 were duplicates. After title/abstract screening, 113 manuscripts were out of the scope of this review and thereby excluded. Therefore, 48 articles qualified for full-test revision. Thirty-five $(n=35)$ articles were excluded due to no CPB surgery or intraoperative ventilation was discussed $(n=27)$, case reports $(n=2)$, protocol design $(n=2)$, trials involving cardiac surgeries in children $(n=1)$, thesis $(n=1)$, and no full-text available $(n=2)$. Therefore, 13 articles were included for further description in our qualitative analysis: systematic review and meta-analysis $(n=1)^{[2]}$, meta-analysis $(n=1)^{[8]}$, randomized clinical trials or RCTs $(n=3)^{[9-11]}$, prospective observational $(n=1)^{[12]}$, and reviews $(n=7)^{[4-6,13-16]}$. Figure 1 describes the flow diagram corresponding to our search.

\section{MV during CPB and serum inflammatory markers}

A total of 3 RCTs and 1 prospective observational trial $(n=157$ patients $)$ studied the impact of intraoperative $\mathrm{MV}$ on inflammatory markers such as cytokines in patients undergoing cardiac surgery with CPB [Table 1 $]^{[9-12]}$. Two RCTs involved one group with low $\mathrm{V}_{\mathrm{T}}(3-4 \mathrm{~mL} / \mathrm{kg}) \mathrm{MV}$ and PEEP whereas no ventilation was administered in a second group ${ }^{[9,10]}$. Another RCT assigned patients to either one of the following groups: patients without MV (MV group), patients receiving protective ventilation with continuous low $\mathrm{V}_{\mathrm{T}}$ ventilation (LTV), and patients with CPAP of $10 \mathrm{cmH}_{2} \mathrm{O}$ (CPAP group) ${ }^{[11]}$. Moreover, one prospective observational study allocated patients into 2 groups based on: MV or apnea with PEEP 


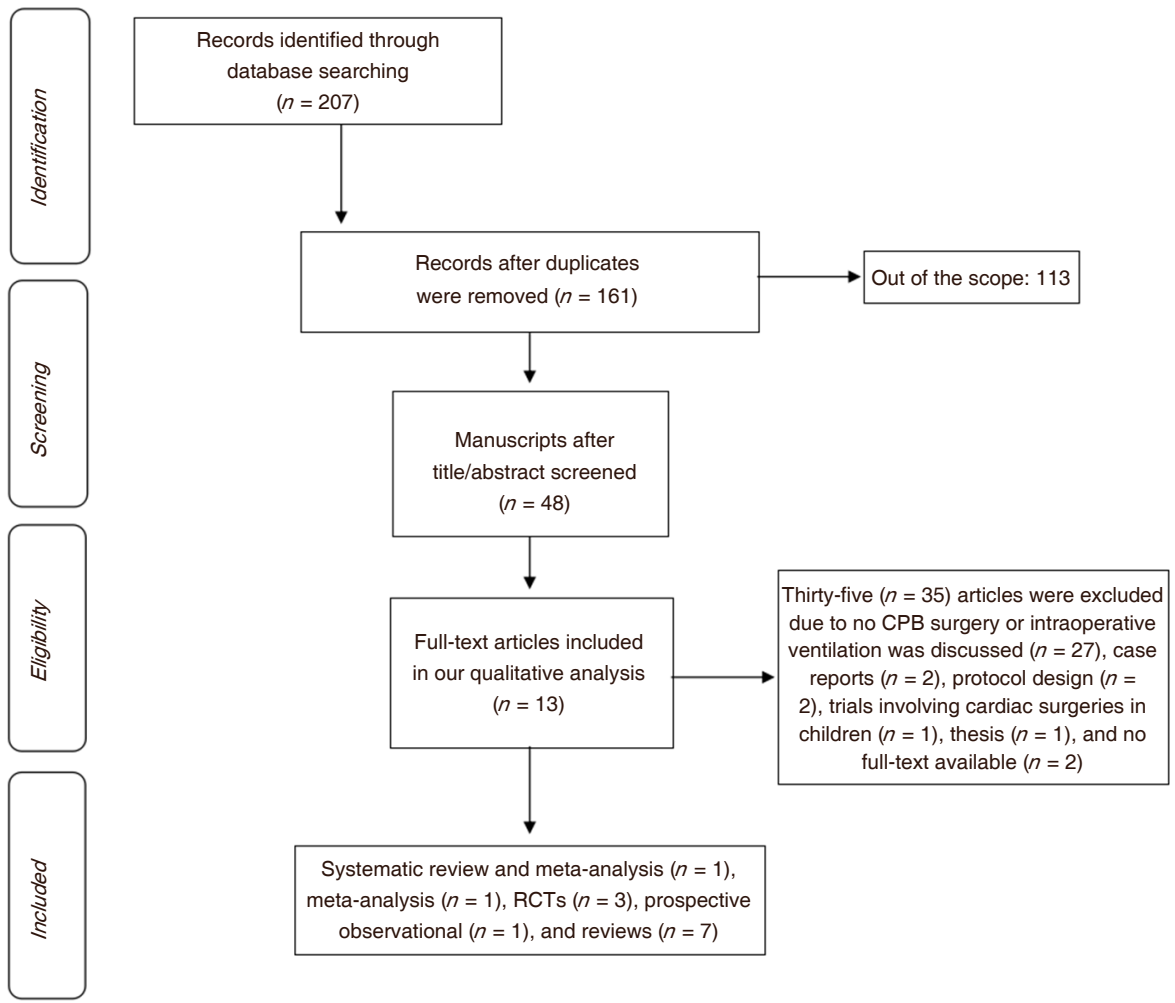

Figure 1. Flow diagram

received during $\mathrm{CPB}^{[12]}$. Analyzed inflammatory markers varied among studies: chemokines (CCL2, CCL4, CCL20 $)^{[9]}$; matrix metalloproteinase (MMP)-8, MMP-9 and lipocalin- $2^{[10]}$; tumor necrosis factor alpha (TNF- $\alpha$ ) and interleukin (IL)-10 ${ }^{[12]}$; and IL-6, IL-8, and IL-10 ${ }^{[11]}$. Table 1 summarizes the main reported findings for each study.

\section{MV during CPB and perioperative outcomes}

Perioperative clinical outcomes (e.g., atrial fibrillation, perioperative myocardial infarction, and pericardial tamponade) and 28-day mortality after cardiac surgery were assessed in 2 of the RCTs included in this review ${ }^{[9,10]}$. Moreover, the ratio between the arterial oxygen partial pressure $\left(\mathrm{PaO}_{2}\right)$ and the inspired fraction of oxygen $\left(\mathrm{FiO}_{2}\right)$ or $\mathrm{PaO}_{2} / \mathrm{FiO}_{2}$ ratio was reported in the only prospective observational study ${ }^{[12]}$. Likewise, one meta-analysis by Chi et al.$^{[8]}$ included 17 trials and 1,162 patients undergoing cardiac surgery evaluating the oxygenation index $\left(\mathrm{PaO}_{2} / \mathrm{FiO}_{2}\right.$ ratio $)$ and the alveolar to arterial oxygen difference $\left(\mathrm{AaDO}_{2}\right)$ after $\mathrm{CPB}$. Rate of PPCs, shunt fraction, hospital LOS, and postoperative $\mathrm{AaDO}_{2}$ (4 h after CPB) were also estimated. Authors used the GRADE system to assess the level of evidence for each outcome [Table 1].

A recent systematic review and meta-analysis described the impact of different MV strategies during CPB on postoperative outcomes in adult patients undergoing cardiac surgery. A total of 15 RCTs were included in this analysis, 13 trials in patients undergoing coronary artery bypass grafting (CABG) and 2 trials in patients undergoing valve surgery. Subsequently, only 5 studies (134 patients in total) reported the use of CPAP during CPB and its impact on oxygenation. Other primary end-points were $\mathrm{PaO}_{2} / \mathrm{FiO}_{2}$ ratio (5 studies), the alveolar-arterial $\mathrm{O}_{2}$ gradient or $\mathrm{P}(\mathrm{A}-\mathrm{a}) \mathrm{O}_{2}$ (9 studies), hospital LOS (6 studies), and the duration of postoperative MV (6 studies) ${ }^{[2]}$.

Seven review manuscripts have summarized some of the current findings in terms of MV strategies and perioperative lung mechanics in patients undergoing cardiac surgery. Table 1 describes the main reported conclusions for each one of them ${ }^{[4-6,14-16]}$. 
Table 1. Summary of the manuscripts included in our review

\begin{tabular}{|c|c|c|c|c|c|}
\hline Authors & Year & $\begin{array}{l}\text { Research } \\
\text { Method }\end{array}$ & $\begin{array}{l}\text { Sample } \\
\text { Size }\end{array}$ & $\begin{array}{c}\text { Main } \\
\text { outcome }\end{array}$ & Comments \\
\hline Bechtel et al. ${ }^{[13]}$ & 2014 & Review & NA & $\begin{array}{l}\text { Describe current } \\
\text { literature about } \\
\text { anesthetic management } \\
\text { in patients undergoing } \\
\text { CPB }\end{array}$ & $\begin{array}{l}\text { Protecting ventilation techniques during CPB may be } \\
\text { associated with decreased inflammatory response. However, } \\
\text { no significant overall improvement in respiratory and } \\
\text { oxygenation parameters has been reported }\end{array}$ \\
\hline Beer et al. ${ }^{[9]}$ & 2014 & RCT & 30 & Chemokines serum levels & $\begin{array}{l}\text { CCL4 serum levels from POD1 to POD5 were significantly } \\
\text { reduced in the ventilated patients when compared to the } \\
\text { non-ventilated group }(P<0.05) \text {. Perioperative clinical } \\
\text { outcomes and } 28 \text {-day mortality were comparable among } \\
\text { groups }\end{array}$ \\
\hline Young $^{[14]}$ & 2014 & Review & NA & $\begin{array}{l}\text { To describe current } \\
\text { strategies to reduce } \\
\text { the postoperative } \\
\text { inflammatory lung injury } \\
\text { in patients undergoing } \\
\text { CPB }\end{array}$ & $\begin{array}{l}\text { Increased resistance in the pulmonary circuit may result } \\
\text { from no ventilation during CPB. Further RCTs are required to } \\
\text { elucidate the impact of mechanical ventilation during CPB } \\
\text { on postoperative pulmonary outcomes }\end{array}$ \\
\hline Beer et al. ${ }^{[10]}$ & 2015 & $\mathrm{RCT}$ & 30 & $\begin{array}{l}\text { Matrix } \\
\text { metalloproteinases levels }\end{array}$ & $\begin{array}{l}\text { Matrix metalloproteinases levels were significantly } \\
\text { reduced at different time-points in patients who underwent } \\
\text { mechanical ventilation during CPB. However, clinical } \\
\text { implications should be addressed in future trials }\end{array}$ \\
\hline Ferrando et $a / .^{[5]}$ & 2015 & Review & NA & $\begin{array}{l}\text { Review pulmonary } \\
\text { protective strategies } \\
\text { during CPB }\end{array}$ & $\begin{array}{l}\text { CPAP, recruitment maneuvers, and low } V_{T} \text { during } C P B \text { have } \\
\text { been associated with better postoperative lung mechanics. } \\
\text { In addition, maintaining certain level of pulmonary perfusion } \\
\text { during CPB may positively impact these outcomes }\end{array}$ \\
\hline Gaudriot et al. ${ }^{[12]}$ & 2015 & $\begin{array}{l}\text { Prospective } \\
\text { Observational }\end{array}$ & 50 & $\begin{array}{l}\text { Impact of Mechanical } \\
\text { ventilation during CPB on } \\
\text { postoperative immune } \\
\text { response }\end{array}$ & $\begin{array}{l}\text { Pro-inflammatory TNF- } \alpha \text { and immunosuppressive IL-10 were } \\
\text { significantly reduced in patients who received mechanical } \\
\text { ventilation during CPB }(P<0.05) \text {. Moreover, non-ventilated } \\
\text { patients had a lower postoperative lymphocyte count when } \\
\text { compared with the ventilated group }(P=0.04) \text {. }\end{array}$ \\
\hline Huffmyer et al. ${ }^{[6]}$ & 2015 & Review & NA & $\begin{array}{l}\text { Pulmonary complications } \\
\text { after CPB: etiology, risk } \\
\text { factors, and prophylaxis }\end{array}$ & $\begin{array}{l}\text { Intermittent ventilation, low } V_{T} \text { and recruitment maneuvers } \\
\text { have been associated with reduced atelectasis and improved } \\
\text { lung mechanics. Mixed results have been reported in terms } \\
\text { of inflammatory markers and clinical outcomes. }\end{array}$ \\
\hline Lellouche et al. ${ }^{[15]}$ & 2015 & Review & NA & $\begin{array}{l}\text { Mechanical ventilation } \\
\text { strategies In patients } \\
\text { undergoing cardiac } \\
\text { surgery }\end{array}$ & $\begin{array}{l}\text { Protective ventilation strategies are associated with } \\
\text { improved lung mechanics, decreased pro-inflammatory } \\
\text { cytokines, and reduced postoperative intubation time and } \\
\text { ICU LOS }\end{array}$ \\
\hline Bignami et al. ${ }^{[16]}$ & 2016 & Review & NA & $\begin{array}{l}\text { Postoperative lung } \\
\text { dysfunction and } \\
\text { mechanical ventilation } \\
\text { strategies to prevent it in } \\
\text { patients undergoing CPB }\end{array}$ & $\begin{array}{l}\text { No ventilation during CPB has been linked to increased } \\
\text { lysosomal enzymes in lungs circulation and increased } \\
\text { incidence of ARDS. Low } \mathrm{V}_{\mathrm{T}} 6-8 \mathrm{~mL} / \mathrm{Kg} \text { of IBW, PEEP, } \\
\text { recruitment maneuvers, and } \mathrm{FiO}_{2}<80 \% \text { have been } \\
\text { associated with decreased morbidity, hospital LOS, and } \\
\text { PPCs. Ventilation before and after the CPB may significantly } \\
\text { affect lung mechanics as well. Mixed results have been } \\
\text { reported in terms of CPAP use during CPB and its association } \\
\text { with improved postoperative pulmonary outcomes. Only } \\
\text { one trial has reported high-frequency ventilation during CPB } \\
\text { with no significant respiratory improvements reported }\end{array}$ \\
\hline Chi et al. ${ }^{[8]}$ & 2017 & Meta-analysis & NA & $\begin{array}{l}\text { Impact of mechanical } \\
\text { ventilation during CPB on } \\
\text { PPCs when compared to } \\
\text { non-ventilated patients }\end{array}$ & $\begin{array}{l}\text { Mechanical ventilation during CPB results in an improved } \\
\text { oxygenation and gas exchanged. However, comparable } \\
\text { incidences of PPCs and hospital LOS have been reported } \\
\text { among groups }\end{array}$ \\
\hline Toikkanen et al. ${ }^{[11]}$ & 2017 & $\mathrm{RCT}$ & 47 & $\begin{array}{l}\text { Mechanical ventilation } \\
\text { and its effect on cytokines } \\
\text { levels after } C A B G\end{array}$ & $\begin{array}{l}\text { CABG with CPB is associated with an increased pro- } \\
\text { inflammatory cytokines pulmonary passage when } \\
\text { compared to patients where CPB was not used. Moreover, } \\
\text { lung ventilation did not change cytokines concentration } \\
\text { in patients undergoing CABG with CPB. Main limitation: } \\
\text { sample size, patient selection (e.g., lung disease was } \\
\text { excluded), and no subgroups (ventilation vs. non-ventilation) } \\
\text { in patients undergoing CABG without CPB }\end{array}$ \\
\hline Bignami et al. ${ }^{[4]}$ & 2018 & Review & NA & $\begin{array}{l}\text { Describe current status } \\
\text { of protective ventilation } \\
\text { strategies and their } \\
\text { impact on postoperative } \\
\text { outcomes }\end{array}$ & $\begin{array}{l}\text { In patients undergoing cardiothoracic surgery, protective } \\
\text { ventilation strategies are associated with a decreased } \\
\text { inflammatory response and should be considered in patients } \\
\text { at high risk of PPCs. CPAP, low } \mathrm{V}_{\mathrm{T}} \text {, and non-ventilated lungs } \\
\text { are among the options for mechanical ventilation during CPB }\end{array}$ \\
\hline
\end{tabular}




\begin{tabular}{llll}
2018 Wang et $a l^{[2]} \quad \begin{array}{l}\text { Systematic } \\
\text { Review and } \\
\text { Meta-analysis }\end{array}$ & NA & $\begin{array}{l}\text { Different strategies used } \\
\text { for mechanical ventilation } \\
\text { during CPB and } \\
\text { postoperative outcomes }\end{array}$ & $\begin{array}{l}\text { CPAP between } 5-15 \mathrm{~cm}_{\mathrm{H}} \mathrm{O} \text { during CPB may be associated } \\
\text { oxygenation. However, no significant differences in these } \\
\text { variables were found when comparing patients undergoing } \\
\text { mechanical ventilation during CPB and those non-ventilated }\end{array}$ \\
\hline
\end{tabular}

CPB: cardiopulmonary bypass; RCT: randomized clinical trial; CCL: chemokine ligand; POD: postoperative day; CPAP: continuous positive airway pressure; VT: tidal volume; TNF- $\alpha$ : tumor necrosis factor alpha; IL: interleukin; ICU: intensive care unit; LOS: length of stay; IBW: ideal body weight; PEEP: positive end-expiratory pressure; FiO2: inspired fraction of oxygen; PPCs: postoperative pulmonary complications; CABG: coronary artery bypass graft; ARDS: acute respiratory distress syndrome

\section{DISCUSSION}

\section{Multifactorial mechanisms affecting pulmonary function during and after CPB}

Postoperative respiratory dysfunction is the most common postoperative complication in patients undergoing cardiac surgery under $\mathrm{CPB}$ affecting $10 \%$ to $25 \%$ of these patients and also associated with high mortality rates ${ }^{[17-19]}$. Patient-specific, anesthesia- and surgery-related factors contribute to the onset of a complex mosaic of pathophysiological events that result in severe respiratory mechanics and gas exchange impairment ensuing postoperative pulmonary dysfunction ${ }^{[18,20-23]}$.

\section{Patient-specific factors}

Chronic obstructive pulmonary disease, low ventricular ejection fraction (EF) (i.e., $\mathrm{EF}<30 \%$ ), hypertension, blood transfusions, emergency surgery, previous cardiac surgery, combined procedures (i.e., cardiac and aortic procedures), active endocarditis, age $>70$ are some of the patient-related risk factors associated with respiratory insufficiency after cardiac surgery ${ }^{[24-26]}$.

\section{Anesthesia-related factors}

Several reports identified a strong association between general anesthesia and impaired postoperative pulmonary function. Prolonged time in supine position and muscle relaxation have been linked to a significant reduction in both, functional residual capacity (FRC) and lung volume, resulting from a cephalic displacement of the diaphragm and the loss of balance between the elastic recoil of the lung and the outward forces of the chest wall. This reduction in FRC promotes alveolar collapse (i.e., atelectasis) and increases airway resistance with subsequent increased resistance to thoracic blood flow circulation. Furthermore, the volatile agents inhibit pulmonary hypoxic vasoconstriction whereas intravenous agents may decrease the hypoxic and hypercapnic ventilatory response. Intubation along with the aforementioned mechanisms may result in ventilation-perfusion mismatch, abnormal shunt fraction, and wider $\mathrm{AaDO}_{2}^{[27,28]}$.

\section{Surgery-related factors}

Sternotomy incision, sternosynthesis, and left internal mammary artery dissection

Numerous reports describe the association between the surgical technique and changes in respiratory mechanics and lung function ${ }^{[22,29-33]}$. Median sternotomy disrupts sternum integrity, provokes chest wall instability (i.e., uncoordinated rib cage expansion, decrease compliance), and reduces lung volumes with subsequent impaired pulmonary mechanics ${ }^{[29,31]}$. The combination of sternotomy and dissection of the left internal mammary artery (LIMA) has a significant impact on respiratory mechanics ${ }^{[29,31]}$. LIMA harvesting maneuvers not only interfere with sternum stability but also may affect blood supply to the sternum, intercostal muscles, and left phrenic nerve functionality. Moreover, instillation of saline slush in the pericardial cavity has been also associated with phrenic nerve injury or dysfunction during cardiovascular surgery $^{[22]}$.Therefore, chest wall mechanics and diaphragm mobility impairment results in significant changes from pre-sternotomy breathing patterns (abdominal) to an upper thoracic pattern with reduced lung volumes thereby, promoting atelectasis ${ }^{[34]}$. Retraction of the chest wall during LIMA harvesting produces additional trauma to the costovertebral joints ensuing an unstable rib cage with impaired diaphragm contraction ${ }^{[34,35]}$. Likewise, altered thoracic wall mechanics and diaphragmatic dysfunction have been associated to a reduced postoperative abdominal motion ${ }^{[22,29,31,34,36]}$. Nevertheless, disruption of the anterior insertions of the diaphragm seems to recover shortly after surgery ${ }^{[37]}$. 
In addition to direct nerve injury (i.e., neuropraxia), the LIMA retractor has been also associated with lesion of the left internal oblique abdominal, external oblique abdominal and rectus abdominis muscles ${ }^{[35,38,39]}$. In contrast, sternotomy with intact pleura maintains respiratory system and chest wall elastance unchanged. However, the opening of the parietal pleura leads to lung collapse with decreased lung elastance and resistance ${ }^{[32]}$. In addition, the use of LIMA for grafting requires the insertion of a pleural subxyphoid or left intercostal tube for drainage, being subxyphoid placement associated with lesser impairment and postoperative pain when compared to intercostal insertion ${ }^{[3,40,41]}$.

\section{Blood transfusion}

Blood transfusion is used in $30 \%-60 \%$ of patients undergoing cardiac surgery and the reported incidence of transfusion-related acute lung injury (TRALI) is $2.5 \%{ }^{[2-44]}$. Blood transfusion has been linked to an increased risk of postoperative morbid events ${ }^{[45]}$, being transfusion of $>3$ red blood cells units an independent risk factor for increased hospital LOS after cardiac surgery ${ }^{[46]}$. Presence of bioactive lipids and antibodies in the stored blood, and the activation of transfused neutrophils in the setting of an exacerbated host's systemic and pulmonary inflammatory response are some of the mechanisms involved in the TRALI $^{[47]}$.

\section{Cardiotomy for suction}

Tissue plasminogen activating factor, pro-inflammatory mediators (i.e., cytokines, activated leukocytes, lipids), pro-coagulants, and platelet factors are present in the cardiotomy suction blood. Numerous reports have shown the detrimental effects associated with these mediators during re-transfusion of unwashed blood collected in the pericardium including an increased inflammatory response with impaired lung function and hemostasis ${ }^{[4,49]}$. Cell savage devices helps to remove these activated mediators from the blood obtained from cardiotomy suction ${ }^{[0,51]}$.

\section{Extracorporeal circulation}

In spite of innovations in biocompatibility of $\mathrm{CPB}$ circuit's surfaces, the inflammatory response associated to extracorporeal circulation with subsequent anti-inflammatory response as well as the ischemia-reperfusion injury, continue to have a significant impact on postoperative morbidity and mortality after cardiac surgery ${ }^{[52]}$. The exposure of plasma proteases to CPB circuit's non-endothelial surface ("contact activation") immediately activates the complement pathways and factor XII (XIIa). Likewise, classic complement pathway is activated by heparin-protamine complexes, coagulation and fibrinolysis byproducts (from the activation of the extrinsic coagulation pathway after vascular injury). Activation of classical and alternative pathway promotes the release of pro-inflammatory cytokines (TNF $\alpha$, IL-1, IL-2, and IL-8), production of activated-polymorphonuclear leukocytes, endothelial cell damage, and capillary permeability ${ }^{[21,52-54]}$. The combination of the aforementioned factors along with ischemia-reperfusion injury results in endothelial, alveolar and interstitial edema, increased airway resistance and atelectasis ${ }^{[21]}$. Moreover, hemodilution (required to prevent embolism and hemolysis during CPB) may exacerbate pulmonary edema ${ }^{[55]}$.

\section{Cessation of ventilation and altered surfactant production and function}

Type II alveolar cell dysfunction, inactivation of large aggregate by alveolar edema fluid, and/or large aggregate leakage across the damaged alveolar capillary membrane are some of the effects of apnea and lung collapse to FRC during $\mathrm{CPB}$, being the inflammatory response triggered by the use of a foreign bypass circuit during extracorporeal circulation ${ }^{[56]}$. These biochemical and functional disturbances significantly affect surfactant concentration and functionality, contributing to the onset of atelectasis. Cyclic alveoli stretch is necessary to produce a signal transduction responsible of stimulating surfactant secretion by Type II alveolar cell ${ }^{[57-59]}$. Therefore, apnea during CPB may significantly reduce surfactant secretion. Govender et al. ${ }^{[60]}$ reported that patients who underwent off-pump coronary bypass with MV using PEEP experienced higher postoperative large aggregate concentrations when compared to patients who 
underwent CABG under CPB. Moreover, absence of ventilation has been associated with hydrostatic pulmonary edema, poor pulmonary compliance, and higher incidence of lung infections ${ }^{[61,62]}$.

\section{Ischemia-reperfusion injury}

Under physiologic conditions, bronchial circulation represents 3\%-4\% of the pulmonary blood flow and may decrease during $\mathrm{CPB}^{[63]}$. The ischemic phase depletes the energy stores (i.e., ATP), increasing lactate levels in the pulmonary blood flow ${ }^{[53,64]}$.The reperfusion and re-oxygenation phase after aortic cross-clamp release stimulates the production of reactive oxygen species (ROS) resulting in dysregulation of intracellular and mitochondrial calcium transport, increased inflammatory response (i.e., cytokines, complement and activation of neutrophils), endothelial cell damage, and increased vascular permeability ${ }^{[60,65-67]}$. The systemic and pulmonary inflammatory states originated during and after CPB generate a compensatory anti-inflammatory response characterized by the production of anti-inflammatory cytokines (IL-10) and leukocytes ${ }^{[68,69]}$. Monocytes downregulation follows this chain of events resulting in an increased susceptibility to postoperative infections ${ }^{[52,70]}$.

\section{Hyperoxia}

Increased oxygen concentrations are commonly administered during CPB in order to avoid cellular hypoxia, reduce gaseous micro-embolism, and improve neutrophils' functionality ${ }^{[71]}$. Nonetheless, enhanced production of ROS, cardiovascular dysregulation, and increased injury due to ischemia-reperfusion are some of the systemic effects linked to hyperoxia ${ }^{[72,73]}$.

\section{Could MV be a mechanistic strategy to protect the lungs during CPB?}

Different strategies such as CPAP with and without PEEP have been implemented during MV under CPB. Current evidence about the use of MV as a mechanistic strategy for lung protection during $\mathrm{CPB}$ remains controversial. Early studies examined the effects of CPAP during CPB without showing any significant beneficial effects on oxygenation ${ }^{[74,75]}$. Nevertheless, recent studies have reported that CPAP pressures of $10 \mathrm{cmH}_{2} \mathrm{O}$ were more effective in achieving and maintaining better postoperative $\mathrm{PaO}_{2} / \mathrm{FIO}_{2}$ ratio than lower CPAP pressures in patients undergoing cardiac surgery with $\mathrm{CPB}^{[61]}$.

Even though only a small amount of patients undergoing cardiac surgery may develop acute respiratory distress syndrome (ARDS), the reported mortality rates may reach up to $50 \%^{[17,24]}$. An increased body of evidence supports the benefits of PMV (low $\mathrm{V}_{\mathrm{T}}, \mathrm{FiO}_{2}$, and PEEP) in patients with $\mathrm{ARDS}{ }^{[76-80]}$. The rationale for using PMV during CPB lies in the fact that postoperative pulmonary dysfunction in cardiac surgery is characterized by alterations in lung mechanics and gas exchange abnormalities, which may resemble some of the ARDS physiologic and clinical features. Although many surgeons prefer the lung collapsed during $\mathrm{CPB}$ in order to improve the surgical field, recent published reports suggest that PMV may be associated with a significant reduction of pathophysiological events and pulmonary dysfunction after cardiac surgery ${ }^{[81-89]}$. However, MV also entails some risk of pulmonary damage such as alveolar over distension (resulting from high $\mathrm{V}_{\mathrm{T}}$ ), alveolar rupture (due to cyclic opening), inactivation of surfactant, and excessive lung stress inducing elevated transpulmonary pressure ${ }^{[90-93]}$.

John and Ervine ${ }^{[84]}$ randomized patients undergoing CABG under CPB to either MV with low $\mathrm{V}_{\mathrm{T}} /$ no-PEEP (ZEEP) or non-ventilation. Patients who were ventilated during CPB presented lower extravascular lung water content and shorter extubation times when compared to the non-ventilation group $(530 \pm 50 \mathrm{~mL}$ vs. $672 \pm 32 \mathrm{~mL}, P=0.028$ and $3.60 \pm 0.3 \mathrm{~h}$ vs. $4.8 \pm 0.4 \mathrm{~h}, P=0.038$ respectively). Paradoxically, the cyclic expansion of the lungs may further reduce the bronchial blood flow during the pulmonary exclusion phase of extracorporeal circulation ${ }^{[94]}$. 
Gagnon et al. ${ }^{[86]}$ studied 40 patients undergoing CABG with CPB. Patients were randomized into two groups, no ventilation (group I) and ventilation with low $\mathrm{V}_{\mathrm{T}}(3 \mathrm{~mL} / \mathrm{kg})$ and ZEEP during CPB. Endothelial function was assessed through the changes in pulmonary vascular resistance index (PVRI) after the injection of acetylcholine (ACh) into the pulmonary artery. Although patients in the ventilated group had a better vasodilatory response to ACh, the difference in PVRI between the two groups was not statistically significant neither after declamping of the aorta $(P=0.32)$ nor at $1 \mathrm{~h}$ after $\mathrm{CPB}(P=0.28)$. In addition, LTV with or without PEEP has been associated with attenuation of the systemic and pulmonary immuneinflammatory response and thereby, its effect in the lungs ${ }^{[9,10,12,87]}$.

\section{MV and pulmonary perfusion during CPB}

Discontinuation of the pulmonary artery circulation during CPB significantly affects the bronchial blood flow and metabolic demand which results in ischemia-reperfusion injury. Nevertheless, maintaining pulmonary circulation and ventilation during $\mathrm{CPB}$ have been associated with reduced ischemia-reperfusion damage in preclinical models ${ }^{[95]}$.

In humans, the impact of continuous pulmonary perfusion during extracorporeal circulation on reducing postoperative lung injury remains controversial ${ }^{[96-98]}$. Santini et al. ${ }^{[96]}$ compared pulsatile pulmonary perfusion during $\mathrm{CPB}$ with conventional $\mathrm{CPB}$ in patients undergoing cardiac surgery. The pulsatile pulmonary perfusion group showed increased $\mathrm{PaO}_{2} / \mathrm{FiO}_{2}$ and lung compliance with reduced neutrophils in the bronchoalveolar lavage when compared to the conventional group. Moreover, pulmonary perfusion has been also associated with an increased postoperative oxygenation when compared to the use of histidine-tryptophan-ketoglutarate solution during CPB in patients undergoing cardiac surgery ${ }^{[97]}$. Even though pulmonary perfusion during $\mathrm{CPB}$ reduces the postoperative inflammatory response and improves oxygenation, long-term benefits are yet to be determined. However, its implementation may considerably increase surgeons' workload.

\section{CONCLUSION}

A variety of MV strategies may have potential benefits in patients undergoing cardiac surgery with CPB. $\mathrm{PMV}$ is a useful mechanistic strategy during $\mathrm{CPB}$ associated with reduced systemic and inflammatory responses and thereby, lung injury. Nevertheless, the impact of these findings on postoperative morbidity and mortality has not been clearly established. Future prospective RCTs should address the need for clinical data describing both, short- and long-term outcomes in patients undergoing cardiac surgeries with $\mathrm{CPB}$ under MV.

\section{DECLARATIONS}

\section{Authors' contributions}

Made substantial contributions to conception and outline of this manuscript: Echeverria-Villalobos M Made substantial contributions to data search, interpretation, and writing: Echeverria-Villalobos M, Munlemvo DM, Fiorda-Diaz J, Essandoh MK

\section{Availability of data and materials}

Not applicable.

\section{Financial support and sponsorship}

None.

\section{Conflicts of interest}

All authors declared that there are no conflicts of interest. 


\section{Ethical approval and consent to participate}

Not applicable.

\section{Consent for publication}

Not applicable.

\section{Copyright}

(C) The Author(s) 2019.

\section{REFERENCES}

1. Park SH. Perioperative lung-protective ventilation strategy reduces postoperative pulmonary complications in patients undergoing thoracic and major abdominal surgery. Korean J Anesthesiol 2016;69:3-7.

2. Wang YC, Huang CH, Tu YK. Effects of Positive Airway Pressure and Mechanical Ventilation of the Lungs During Cardiopulmonary Bypass on Pulmonary Adverse Events After Cardiac Surgery: A Systematic Review and Meta-Analysis. J Cardiothorac Vasc Anesth 2018;32:748-59.

3. Butler J, Rocker GM, Westaby S. Inflammatory response to cardiopulmonary bypass. Ann Thorac Surg 1993;55:552-9.

4. Bignami E, Saglietti F, Di Lullo A. Mechanical ventilation management during cardiothoracic surgery: an open challenge. Ann Transl Med 2018;6:380.

5. Ferrando C, Soro M, Belda FJ. Protection strategies during cardiopulmonary bypass: ventilation, anesthetics and oxygen. Curr Opin Anaesthesiol 2015;28:73-80.

6. Huffmyer JL, Groves DS. Pulmonary complications of cardiopulmonary bypass. Best Pract Res Clin Anaesthesiol 2015;29:163-75.

7. Szerafin T, Niederpold T, Mangold A, Hoetzenecker K, Hacker S, et al. Secretion of soluble ST2 - possible explanation for systemic immunosuppression after heart surgery. Thorac Cardiovasc Surg 2009;57:25-29.

8. Chi D, Chen C, Shi Y, Wang W, Ma Y, et al. Ventilation during cardiopulmonary bypass for prevention of respiratory insufficiency: A meta-analysis of randomized controlled trials. Medicine (Baltimore) 2017;96:e6454.

9. Beer L, Szerafin T, Mitterbauer A, Debreceni T, Maros T, et al. Low tidal volume ventilation during cardiopulmonary bypass reduces postoperative chemokine serum concentrations. Thorac Cardiovasc Surg 2014;62:677-82.

10. Beer L, Warszawska JM, Schenk P, Debreceni T, Dworschak M, et al. Intraoperative ventilation strategy during cardiopulmonary bypass attenuates the release of matrix metalloproteinases and improves oxygenation. J Surg Res

2015;195:294-302.

11. Toikkanen V, Rinne T, Nieminen R, Moilanen E, Laurikka J, et al. The Impact of Lung Ventilation on Some Cytokines after Coronary Artery Bypass Grafting. Scand J Surg 2017;106:87-93.

12. Gaudriot B, Uhel F, Gregoire M, Gacouin A, Biedermann S, et al. Immune Dysfunction After Cardiac Surgery with Cardiopulmonary Bypass: Beneficial Effects of Maintaining Mechanical Ventilation. Shock (Augusta, Ga) 2015;44:228-33.

13. Bechtel A, Huffmyer J. Anesthetic Management for Cardiopulmonary Bypass: Update for 2014. Semin Cardiothorac Vasc Anesth2014;18:101-16.

14. Young RW. Prevention of lung injury in cardiac surgery: a review. J Extra Corpor Technol 2014;46:130-41.

15. Lellouche F, Delorme M, Bussieres J, Ouattara A. Perioperative ventilatory strategies in cardiac surgery. Best Pract Res Clin Anaesthesiol 2015;29:381-95.

16. Bignami E, Guarnieri M, Saglietti F, Belletti A, Trumello C, et al. Mechanical Ventilation During Cardiopulmonary Bypass. J Cardiothorac Vasc Anesth 2016;30:1668-75.

17. Asimakopoulos G, Taylor KM, Smith PL, Ratnatunga CP. Prevalence of acute respiratory distress syndrome after cardiac surgery. J Thorac Cardiov Sur 1999;117:620-1.

18. Ng CS, Wan S, Yim AP, Arifi AA. Pulmonary dysfunction after cardiac surgery. Chest 2002;121:1269-77.

19. Messent M, Sullivan K, Keogh B, Morgan C, Evans T. Adult respiratory distress syndrome following cardiopulmonary bypass: incidence and prediction. Anaesthesia 1992;47:267-8.

20. Wynne R, Botti M. Postoperative pulmonary dysfunction in adults after cardiac surgery with cardiopulmonary bypass: clinical significance and implications for practice. Am J Crit Care 2004;13:384-93.

21. Apostolakis E, Filos KS, Koletsis E, Dougenis D. Lung dysfunction following cardiopulmonary bypass. J Cardiac Surg 2010;25:47-55.

22. Aguirre VJ, Sinha P, Zimmet A, Lee GA, Kwa L, et al. Phrenic nerve injury during cardiac surgery: mechanisms, management and prevention. Heart Lung Circ 2013;22:895-902.

23. Boldt J, King D, Scheid H, Hempelmann G. Lung management during cardiopulmonary bypass: influence on extravascular lung water. J Cardiothorac Anesth 1990;4:73-9.

24. Milot J, Perron J, Lacasse Y, Létourneau L, Cartier PC, et al. Incidence and predictors of ARDS after cardiac surgery. Chest 2001;119:884-8.

25. Bailey ML, Richter SM, Mullany DV, Tesar PJ, Fraser JF. Risk factors and survival in patients with respiratory failure after cardiac 
operations. Ann Thorac Surg 2011;92:1573-9.

26. Filsoufi F, Rahmanian PB, Castillo JG, Chikwe J, Adams DH. Predictors and early and late outcomes of respiratory failure in contemporary cardiac surgery. Chest 2008;133:713-21.

27. Hedenstierna G, Strandberg A, Brismar B, Lundquist H, Svensson L, et al. Functional residual capacity, thoracoabdominal dimensions, and central blood volume during general anesthesia with muscle paralysis and mechanical ventilation. Anesthesiology 1985;62:247-54.

28. Hedenstierna G, Edmark L. Effects of anesthesia on the respiratory system. Best Pract Res Clin Anaesthesiol 2015;29:273-84.

29. Berrizbeitia LD, Tessler S, Jacobowitz IJ, Kaplan P, Cunningham JN. Effect of sternotomy and coronary bypass surgery on postoperative pulmonary mechanics: comparison of internal mammary and saphenous vein bypass grafts. Chest 1989;96:873-6.

30. Chetta A, Bobbio A, Aiello M, Del Donno M, Castagnaro A, et al. Changes in lung function and respiratory muscle strength after sternotomy vs. laparotomy in patients without ventilatory limitation. Eur Surg Res 2006;38:489-93.

31. Locke T, Griffiths T, Mould H, Gibson G. Rib cage mechanics after median sternotomy. Thorax 1990;45:465-8.

32. Barnas GM, Gilbert TB, Watson RJ, Sequeira AJ, Roitman K, et al. Respiratory mechanics in the open chest: effects of parietal pleurae. Resp Physiol 1996;104:63-70.

33. Ozelami IV, Vieira F, Abrao J, Gastaldi A. Influence of pleural drain insertion in lung function of patients undergoing coronary artery bypass grafting. Rev Bras Anestesiol 2012;62:696-708.

34. Ragnarsdottir M, Kristjansdottir A, Ingvarsdóttir I, Hannesson P, Torfason B, et al. Short $\square$ term changes in pulmonary function and respiratory movements after cardiac surgery via median sternotomy. Scand Cardiovasc J 2004;38:46-52.

35. Kristjansdottir A, Ragnarsdottir M, Hannesson P, Beck HJ, Torfason B. Chest wall motion and pulmonary function are more diminished following cardiac surgery when the internal mammary artery retractor is used. Scand Cardiovasc J 2004;38:369-74.

36. Marco JD, Hahn JW, Barner HB. Topical cardiac hypothermia and phrenic nerve injury. Ann Thorac Surg 1977;23:235-7.

37. Fedullo AJ, Lerner RM, Gibson J, Shayne DS. Sonographic measurement of diaphragmatic motion after coronary artery bypass surgery. Chest 1992;102:1683-6.

38. Cohen AJ, Katz MG, Katz R, Mayerfeld D, Hauptman E, et al. Phrenic nerve injury after coronary artery grafting: is it always benign? Ann Thorac Surg 1997; 64:148-53.

39. Chandler KW, Rozas CJ, Kory RC, Goldman AL. Bilateral diaphragmatic paralysis complicating local cardiac hypothermia during open heart surgery. Am J Med 1984;77:243-9.

40. Hagl C, Harringer W, Gohrbandt B, Haverich A. Site of pleural drain insertion and early postoperative pulmonary function following coronary artery bypass grafting with internal mammary artery. Chest 1999;115:757-61.

41. Vieira IBCO, Vieira FF, Abrão J, Gastaldi AC. Influence of pleural drain insertion in lung function of patients undergoing coronary artery bypass grafting. Rev Bras Anestesiol 2012;62:702-8.

42. Stover PE, Siegel LC, Parks R, Levin J, Body SC, et al. Variability in transfusion practice for coronary artery bypass surgery persists despite national consensus guidelines a 24-institution study. Anesthesiology: JASA 1998;88:327-33.

43. Salengros JC, Huybrechts I, Ducart A, Faraoni D, Marsala C, et al. Different anesthetic techniques associated with different incidences of chronic post-thoracotomy pain: low-dose remifentanil plus presurgical epidural analgesia is preferable to high-dose remifentanil with postsurgical epidural analgesia. J Cardiothorac Vasc Anesth 2010;24:608-16.

44. Kilic A, Whitman GJ. Blood transfusions in cardiac surgery: indications, risks, and conservation strategies. Ann Thorac Surg 2014;97:726-34.

45. Koch CG, Li L, Duncan AI, Mihaljevic T, Cosgrove DM, et al. Morbidity and mortality risk associated with red blood cell and bloodcomponent transfusion in isolated coronary artery bypass grafting. Crit Care Med 2006;34:1608-16.

46. Galas FR, Almeida JP, Fukushima JT, Osawa EA, Nakamura RE, et al. Blood transfusion in cardiac surgery is a risk factor for increased hospital length of stay in adult patients. J Cardiothorac Surg 2013;8:54.

47. Vlaar AP, Hofstra JJ, Determann RM, Veelo DP, Paulus F, et al. The incidence, risk factors, and outcome of transfusion-related acute lung injury in a cohort of cardiac surgery patients: a prospective nested case-control study. Blood 2011;117:4218-25.

48. de Haan J, Boonstra PW, Monnink SH, Ebels T, van Oeveren W. Retransfusion of suctioned blood during cardiopulmonary bypass impairs hemostasis. Ann Thorac Surg 1995;59:901-7.

49. Westerberg M, Bengtsson A, Jeppsson A. Coronary surgery without cardiotomy suction and autotransfusion reduces the postoperative systemic inflammatory response. Ann Thorac Surg 2004;78:54-9.

50. Damgaard S, Nielsen CH, Andersen LW, Bendtzen K, Tvede M, et al. Cell saver for on-pump coronary operations reduces systemic inflammatory markers: a randomized trial. Ann Thorac Surg 2010;89:1511-7.

51. Allen SJ, McBride WT, McMurray TJ, Phillips AS, Penugonda SP, et al. Cell salvage alters the systemic inflammatory response after off-pump coronary artery bypass grafting surgery. Ann Thorac Surg 2007;83:578-85.

52. Bronicki RA, Hall M. Cardiopulmonary bypass-induced inflammatory response: pathophysiology and treatment. Pediatric Crit Care Med 2016;17:S272-8.

53. Serraf A, Robotin M, Bonnet N, Détruit H, Baudet B, et al. Alteration of the neonatal pulmonary physiology after total cardiopulmonary bypass. J Thorac Cardiov Sur 1997;114:1061-9.

54. Royston D. The inflammatory response and extracorporeal circulation. J Cardiothor Vasc An 1997;11:341-54.

55. DeFoe GR, Ross CS, Olmstead EM, Surgenor SD, Fillinger MP, et al. Lowest hematocrit on bypass and adverse outcomes associated with coronary artery bypass grafting. Ann Thorac Surg 2001;71:769-76.

56. Griese M, Wilnhammer C, Jansen S, Rinker C. Cardiopulmonary bypass reduces pulmonary surfactant activity in infants. J Thorac 
Cardiov Sur 1999;118:237-44.

57. Liu M, Tanswell AK, Post M. Mechanical force-induced signal transduction in lung cells. Am J Physiol 1999;277:L667-83.

58. Nicholas T. Control of turnover of alveolar surfactant. Physiology 1993;8:12-8.

59. Nicholas TE, Power JH, Barr HA. The pulmonary consequences of a deep breath. Resp Physiol 1982;49:315-24.

60. Govender M, Bihari S, Bersten AD, De Pasquale CG, Lawrence MD, et al. Surfactant and lung function following cardiac surgery. Heart Lung 2019;48:55-60.

61. Loeckinger A, Kleinsasser A, Lindner KH, Margreiter J, Keller C, et al. Continuous positive airway pressure at $10 \mathrm{~cm} \mathrm{H} 2 \mathrm{O}$ during cardiopulmonary bypass improves postoperative gas exchange. Anesth Analg 2000;91:522-7.

62. Magnusson L, Zemgulis V, Tenling A, Wernlund J, Tyden H, et al. Use of a Vital Capacity Maneuver to Prevent Atelectasis after Cardiopulmonary Bypass An Experimental Study. Anesthesiology: JASA 1998;88:134-42.

63. Schlensak C, Doenst T, Preußer S, Wunderlich M, Kleinschmidt M, et al. Bronchial artery perfusion during cardiopulmonary bypass does not prevent ischemia of the lung in piglets: assessment of bronchial artery blood flow with fluorescent microspheres. Eur J Cardiothorac Surg 2001;19:326-32.

64. Gasparovic H, Plestina S, Sutlic Z, Husedzinovic I, Coric V, et al. Pulmonary lactate release following cardiopulmonary bypass. Eur J Cardiothorac Surg 2007;32:882-7.

65. Ferrari RS, Andrade CF. Oxidative stress and lung ischemia-reperfusion injury. Oxid Med Cell Longev 2015;2015:590987.

66. Frank A, Bonney M, Bonney S, Weitzel L, Koeppen M, et al. Myocardial ischemia reperfusion injury: from basic science to clinical bedside. Semin Cardiothorac Vasc Anesth 2012;16:123-32.

67. Maltesen R, Buggeskov K, Andersen C, Plovsing R, Wimmer R, et al. Lung Protection Strategies during Cardiopulmonary Bypass Affect the Composition of Bronchoalveolar Fluid and Lung Tissue in Cardiac Surgery Patients. Metabolites 2018;8:54.

68. Yang Z, Zingarelli B, Szabó C. Crucial role of endogenous interleukin-10 production in myocardial ischemia/reperfusion injury. Circulation 2000;101:1019-26.

69. Ward NS, Casserly B, Ayala A. The compensatory anti-inflammatory response syndrome (CARS) in critically ill patients. Clin Chest Med 2008;29:617-25.

70. Allen ML, Hoschtitzky JA, Peters MJ, Elliott M, Goldman A, et al. Interleukin-10 and its role in clinical immunoparalysis following pediatric cardiac surgery. Crit Care Med 2006;34:2658-65.

71. Young RW. Hyperoxia: a review of the risks and benefits in adult cardiac surgery. J Extra Corpor Technol 2012;44:241.

72. Heinrichs J, Lodewyks C, Neilson C, Abou-Setta A, Grocott HP. The impact of hyperoxia on outcomes after cardiac surgery: a systematic review and narrative synthesis. Can J Anesth/J Can Anesth 2018;65:923-35.

73. Spoelstra $\square$ de Man A, Smit B, Oudemans $\square$ van Straaten H, Smulders Y. Cardiovascular effects of hyperoxia during and after cardiac surgery. Anaesthesia 2015;70:1307-19.

74. Berry C, Butler P, Myles P. Lung management during cardiopulmonary bypass: is continuous positive airways pressure beneficial? Brit J Anaesth 1993;71:864-8.

75. Stanley TH, Liu WS, Gentry S. Effects of ventilatory techniques during cardiopulmonary bypass on post-bypass and postoperative pulmonary compliance and shunt. Anesthesiology 1977;46:391-5.

76. Matthay MA, Ware LB, Zimmerman GA. The acute respiratory distress syndrome. J Clin Invest 2012;122:2731-40.

77. Fuller BM, Mohr NM, Drewry AM, Carpenter CR. Lower tidal volume at initiation of mechanical ventilation may reduce progression to acute respiratory distress syndrome: a systematic review. Critical Care 2013;17:R11.

78. Neto AS, Cardoso SO, Manetta JA, Pereira VGM, Espósito DC, et al. Association between use of lung-protective ventilation with lower tidal volumes and clinical outcomes among patients without acute respiratory distress syndrome: a meta-analysis. Jama 2012;308:1651-9.

79. Neto AS, Simonis FD, Barbas CS, Biehl M, Determann RM, et al. Lung-protective ventilation with low tidal volumes and the occurrence of pulmonary complications in patients without acute respiratory distress syndrome: a systematic review and individual patient data analysis. Crit Care Med 2015;43:2155-163.

80. Zupancich E, Paparella D, Turani F, Munch C, Rossi A, et al. Mechanical ventilation affects inflammatory mediators in patients undergoing cardiopulmonary bypass for cardiac surgery: a randomized clinical trial. J Thorac Cardiov Sur 2005;130:378-83.

81. Ng CS, Arifi AA, Wan S, Ho AM, Wan IY, et al. Ventilation during cardiopulmonary bypass: impact on cytokine response and cardiopulmonary function. Ann Thorac Surg 2008;85:154-62.

82. Beer L, Warszawska JM, Schenk P, Debreceni T, Dworschak M, et al. Intraoperative ventilation strategy during cardiopulmonary bypass attenuates the release of matrix metalloproteinases and improves oxygenation. J Surg Res 2015;195:294-302.

83. Network ARDS. Ventilation with lower tidal volumes as compared with traditional tidal volumes for acute lung injury and the acute respiratory distress syndrome. N Engl J Med 2000;342:1301-8.

84. John LC, Ervine IM. A study assessing the potential benefit of continued ventilation during cardiopulmonary bypass. Interact Cardiov Thor Sur 2008; 7:14-7.

85. Davoudi M, Farhanchi A, Moradi A, Bakhshaei MH, Safarpour G. The effect of low tidal volume ventilation during cardiopulmonary bypass on postoperative pulmonary function. J Tehran Heart Cent 2010;5:128-31.

86. Gagnon J, Laporta D, Béïque F, Langlois Y, Morin JF. Clinical relevance of ventilation during cardiopulmonary bypass in the prevention of postoperative lung dysfunction. Perfusion 2010;25:205-10.

87. Beer L, Szerafin T, Mitterbauer A, Debreceni T, Maros T, et al. Continued mechanical ventilation during coronary artery bypass graft operation attenuates the systemic immune response. Eur J Cardiothorac Surg 2012;44:282-7. 
88. Beer L, Szerafin T, Mitterbauer A, Debreceni T, Maros T, et al. Low tidal volume ventilation during cardiopulmonary bypass reduces postoperative chemokine serum concentrations. Thorac Cardiovasc Surg 2014;62:677-82.

89. Naseer M, Siddiqi R, Hussain A, Tehniat I, Bashir I. Effects of low volume ventilation during cardiopulmonary bypass on postoperative pulmonary outcome after coronary artery bypass grafting. Pakistan Armed Forc Med J 2017;67:237-41.

90. Parker JC, Hernandez LA, Peevy KJ. Mechanisms of ventilator-induced lung injury. Crit Care Med 1993;21:131-43.

91. Pelosi P, Negrini D. Extracellular matrix and mechanical ventilation in healthy lungs: back to baro/volotrauma? Curr Opin Crit Care 2008; $14: 16-21$.

92. Spieth P, Bluth T, Gama MDA, Bacelis A, Goetz A, et al. Mechanotransduction in the lungs. Minerva anestesiologica 2014;80:933-41.

93. Tonetti T, Vasques F, Rapetti F, Maiolo G, Collino F, et al. Driving pressure and mechanical power: new targets for VILI prevention. Ann Transl Med 2017;5:286.

94. Deffebach M. Lung mechanical effects on the bronchial circulation. Eur Respir J Suppl 1990;12:586s-90s.

95. da Costa F, Regina C, Malbouisson S, Marcelo L, Benicio A, et al. Lung perfusion and ventilation during cardiopulmonary bypass reduces early structural damage to pulmonary parenchyma. Anesth Analg 2016;122:943-52.

96. Santini F, Onorati F, Telesca M, Patelli F, Berton G, et al. Pulsatile pulmonary perfusion with oxygenated blood ameliorates pulmonary hemodynamic and respiratory indices in low-risk coronary artery bypass patients. Eur J Cardiothorac Surg 2011;40:794-803.

97. Buggeskov KB, Sundskard MM, Jonassen T, Andersen LW, Secher NH, et al. Pulmonary artery perfusion versus no pulmonary perfusion during cardiopulmonary bypass in patients with COPD: a randomised clinical trial. BMJ Open Respirat Res 2016;3:e000146.

98. Rodriguez-Blanco YF, Gologorsky A, Salerno TA, Lo K, Gologorsky E. Pulmonary Perfusion and Ventilation during cardiopulmonary Bypass are not associated with improved Postoperative Outcomes after cardiac surgery. Front Cardiovas Med 2016;3:47. 